\title{
The Relationship between Proliferative Scars and Endothelial Function in Surgically Revascularized Patients
}

\author{
Murat Ziyrek ${ }^{1}$, Sinan Şahin², Zeydin Acar ${ }^{1}$, Onur Şen $^{3}$ \\ ${ }^{1}$ Department of Cardiology, Karadeniz Hospital, Trabzon, Turkey \\ ${ }^{2}$ Department of Cardiology, Kanuni Training and Research Hospital, Trabzon, Turkey \\ ${ }^{3}$ Department of Cardiovascular Surgery, Mehmet Akif Ersoy Thoracic and Cardiovascular Surgery Training and Research Hospital, İstanbul, Turkey
}

Background: Proliferative scars are benign fibrotic proliferations which demonstrate abnormal wound healing in response to skin injuries. As postulated in the "response to injury hypothesis", atherosclerosis is also triggered by an endothelial injury. Keloid and atherosclerotic processes have many pathophysiological and cytological features in common.

Aims: In this study, we investigated the relationship between proliferative scars and endothelial function in surgically revascularized patients. We aimed to test the hypothesis that atherosclerosis is a wound healing abnormality.

Study Design: Cross-sectional study.

Methods: Consecutive patients who were admitted to the cardiology outpatient clinic with a history of coronary artery bypass grafting operation were evaluated. Thirty-three patients with proliferative scars at the median sternotomy site formed the keloid group, and 36 age- and sex-matched patients with no proliferative scar at the median sternotomy site formed the control group. Endothelial function was evaluated by flowmediated vasodilatation of the brachial artery via ultrasonograhic examination.

Results: There is no signicant difference according to the demographic data, biochemical parameters, clinical parameters and number of grafts between keloid and control groups. Endothelial-dependent vasodilatory response was lower in the keloid group than the control group $(9.30 \pm 3.5$ and $18.68 \pm 8.2$, respectively; $\mathrm{p}=0.001$ ).

Conclusion: This study showed that endothalial dysfunction, which is strongly correlated with atherosclerosis, was more prominent in patients with proliferative scars. As proliferative scars and atherosclerosis have many features in common, we might conclude that atherosclerosis is a wound healing abnormality.

Keywords: Endothelium, keloid, cicatrix, wound healing
Atherosclerosis is a chronic pathophysiological process consisting of complex molecular mechanisms and inflammatory pathways (1-3). Atherosclerosis is the major cause of cardiovascular diseases such as myocardial infarction, stroke, and peripheral vascular disease, all of which are highly prevalent in the western world $(4,5)$. Understandably, the commanding importance of atherosclerosis has stimulated enormous efforts to discover its cause, and a number of hypotheses for its pathogenesis have been proposed. Although various theories are present, the one receiving greatest attention is the response-to-injury hypothesis (RTIH). Chronic or repeated endothelial injury is the keystone of the RTIH. Experiments 
in animal models have demonstrated increased cell turnover rates in lesion-prone regions in the arterial tree $(6,7)$. Repetitious endothelial injury stimulates the healing process, which might constitute the atherosclerotic core (8).

Keloid and hypertrophic scars are two types of proliferative scars that enlarge beyond the wound margins at the sites of cutaneous injury (Figure 1) (9). The pathogenesis of proliferative scars is not clear. They demonstrate abnormal woundhealing responses in susceptible individuals (10). Both atherosclerosis and proliferative scars have cytologically and pathophysiologically common features. Response to an injury pulls the trigger; fibroblasts, macrophages/monocytes, endothelial cells, and chronic inflammatory processes contribute to the development of both proliferative scars and atheroscle$\operatorname{rosis}(11,12)$.

In this study, we aimed to investigate the relationship between proliferative scars and endothelial function in surgically revascularized patients to test the hypothesis that atherosclerosis is a wound healing abnormality.

\section{MATERIALS AND METHODS}

\section{Study population}

In this observational cross-sectional study, consecutive patients who were admitted to the cardiology outpatient clinic with a history of coronary artery bypass grefting (CABG) operation between January 2011 and May 2013 were evaluated. Patients with incision scars other than median sternotomy, with known wound healing abnormalities, operated upon within a year, using corticosteroids or immunosuppressive drugs for longer than 1 month, previously treated for proliferative scars were excluded. Thirty-three patients with proliferative scars at the median sternotomy site formed the keloid group, and 36 age- and sex-matched patients with no proliferative scar at the median sternotomy site formed the control group. All patients were informed about the study and written informed consent was obtained. The local ethics committee approved the study.

\section{Study protocol}

Clinical and demographic features of keloid and control groups were obtained. Venous blood samples for biochemical analyses were drawn from all subjects after an overnight fasting. Triglyceride (TG), total cholesterol, low density lipoprotein (LDL), high density lipoprotein (HDL), blood urea nitrogen (BUN), creatinine, fasting plasma glucose level were analyzed. Endothelial functions of all subjects were assessed by endothelial-dependent vasodilatory response (EDVR) via brachial artery.

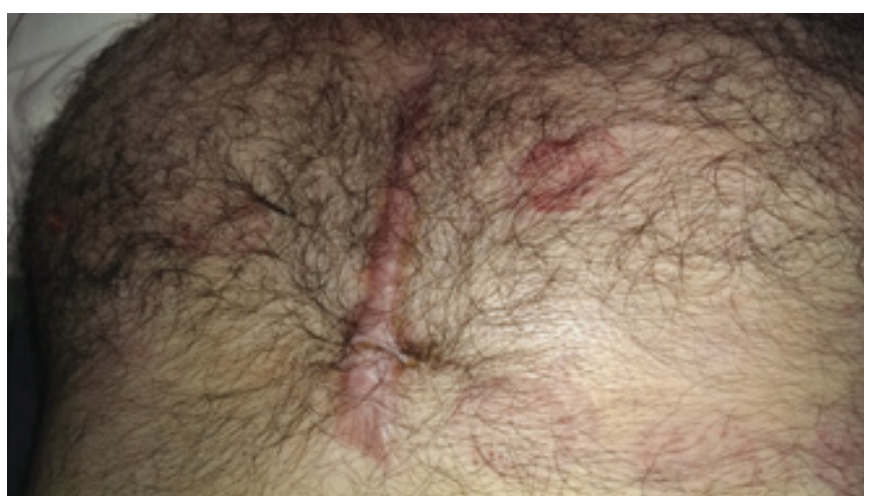

FIG. 1. An example of proliferative scar tissue arround the margins of incision site

\section{Endothelial function assesment}

Subjects were evaluated after an overnight fasting, without smoking, drinking alcohol/coffee, taking vasoactive drugs or taking antioxidant vitamins 12 hours prior to testing. All measurements were taken by experienced physicians who were blinded to the subjects' group. Subjects were examined in the supine position after 15 minutes in a dark and quiet room with a temperature of $20-25^{\circ} \mathrm{C}$. Endothelium-dependent dilation of the brachial artery was measured noninvasively using a 4-12 $\mathrm{MHz}$ linear array transducer high resolution ultrasound system (Vivid-e; General Electric, North Grandview Waukesha, USA). The left arm was immobilized in the extended position to allow consistent access to the brachial artery for imaging. Baseline brachial artery diameter (BAD) was recorded twice at intervals of 1 minute. Following baseline establishment, a blood pressure cuff was placed over the ipsilateral upper arm just above the transducer and inflated for 5 minutes at $50 \mathrm{mmHg}$ greater than systolic blood pressure. The cuff was then suddenly deflated and blood flow velocity was measured immediately after deflation of the cuff (hyperemic blood flow) as well as 60, 75, 90 and 120 seconds later. Maximal brachial artery diameter observed during this time period was used to calculate flow mediated dilatation (FMD). Endothelial dependent vasodilatory response (EDVR) was calculated as follows: $\mathrm{EDVR}=[(\mathrm{FMD}-\mathrm{BAD}) / \mathrm{BAD}] \times 100(13)$.

\section{Statistical analysis}

Statistical analyses were conducted using a commercially available software package (SPSS version 16.0; IBM, Chichago, USA). In this study, data are expressed as mean \pm SD for continuous variables and as counts and percentage for categorical variables. Student's t-test was used for the comparison of continuous variables, while the Chi-square and Fisher's exact tests were used for comparison of categorical variables. 


\section{RESULTS}

Clinical and demographic characteristics of the keloid and control groups are presented in Table 1. Thirty-three patients formed the keloid group and 36 patients formed the control group. Mean age was $61.12 \pm 9.28$ in keloid group and $63.17 \pm 9.42$ in the control group. Overall, 29 out of 33 $(87.8 \%)$ keloid patients and 30 out of $36(83.3 \%)$ control patients were male. There were no significant differences regarding clinical, demographic and laboratory characteristics between keloid and control groups except fasting blood glucose $(106.03 \pm 17.46$ vs. $116.56 \pm 45.71$ respectively; $\mathrm{p}=0.02)$

When we evaluate endothelial function, BAD was significantly higher in the keloid group ( $37.7 \pm 4.03$ vs $35.0 \pm 4.59$; $\mathrm{p}=0.012$ ) and EDVR was significantly higher in the control group $(9.30 \pm 3.56$ vs $18.68 \pm 8.21 ; \mathrm{p}<0.001)$. FMD was also higher in the control group; however the difference was not statistically significant $(41.18 \pm 3.91$ vs $42.50 \pm 4.36$; $\mathrm{p}=0.55)$ Table 2.

\section{DISCUSSION}

In this study we demonstrated that endothelial dysfunction was significantly more prominent in keloid group. This might support the idea that atherosclerosis is a wound healing abnormality.

Wound healing is a complex but systematic process which involves stages that have been well-described previously, namely: 1- induction of an acute inflammatory response by the initial injury, 2- parenchymal cell regeneration, 3- migration and proliferation of both parenchymal and connective tissue cells, 4- synthesis of extracellular matrix (ECM) protein, 5 - remodeling of parenchymal elements to restore tissue function, and 6- remodeling of connective tissue to achieve wound strength (14). Actually, the injury which pulls the trigger initiates the stepwise response to this injury. In wound healing, normal cell growth and fibrosis may be altered by a variety of influences, frequently reducing the quality and adequacy of the reparative process.

Keloids are common fibroproliferative lesions characterized by exuberant extracellular matrix deposition. Fibroblasts derived from keloid scars express excessive amounts of vascular endothelial growth factor (VEGF), tissue growth factor beta (TGF- $\beta$ ), platelet derived growth factor alfa (PDGF- $\alpha$ ) receptors and produce excessive amounts of type 1 procollagen (15). Especially, TGF- $\beta$ is a potent profibrotic factor, which strongly induces collagen synthesis, and plays a pivotal role in keloid pathogenesis $(16,17)$. Wang et al. (18) demon-
TABLE 1. Demographical, biochemical and clinical characteristics of keloid and control groups

\begin{tabular}{lccc}
\hline Parameter & $\begin{array}{c}\text { Keloid } \\
\text { group }\end{array}$ & $\begin{array}{c}\text { Control } \\
\text { group }\end{array}$ & $\begin{array}{c}\mathrm{p} \\
\text { value }\end{array}$ \\
\hline Number of patients & 33 & 36 & \\
Age (year) & $61.12 \pm 9.28$ & $63.17 \pm 9.42$ & 0.37 \\
Gender (male/female) & $29 / 4$ & $30 / 6$ & 0.27 \\
DM n (\%) & $9(27.2)$ & $11(30.5)$ & 0.52 \\
Hypertension n (\%) & $18(54.5)$ & $22(61.1)$ & 0.43 \\
Smoking n (\%) & $3(9.0)$ & $2(5.5)$ & 0.72 \\
Fasting blood glucose (mg/dL) & $106.03 \pm 17.46$ & $116.56 \pm 45.71$ & 0.02 \\
BUN (mg/dL) & $17.88 \pm 4.36$ & $18.92 \pm 5.04$ & 0.36 \\
Creatinine (mg/dL) & $0.93 \pm 0.15$ & $1.27 \pm 0.51$ & 0.20 \\
Cholesterol (mg/dL) & $163.16 \pm 31.47$ & $179 \pm 49.89$ & 0.12 \\
LDL (mg/dL) & $102.28 \pm 29.98$ & $112.28 \pm 34.86$ & 0.20 \\
HDL (mg/dL) & $39.03 \pm 4.11$ & $39.06 \pm 6.65$ & 0.98 \\
Triglyceride (mg/dL) & $177.62 \pm 86.85$ & $161.72 \pm 82.79$ & 0.44 \\
Number of bypass grafts & $2.79 \pm 1.05$ & $2.75 \pm 0.84$ & 0.86 \\
\hline DM: diabetes mellitus; BUN: blood urea nitrogen; LDL: low density lipoprotein; \\
HDL: high density lipoprotein; Data are presented as mean \pm SD and number (percent- \\
age) & & &
\end{tabular}

TABLE 2. Comparison of endothelial function between keloid and control groups

\begin{tabular}{lccc}
\hline Parameters & $\begin{array}{c}\text { Keloid } \\
\text { group }\end{array}$ & $\begin{array}{c}\text { Control } \\
\text { group }\end{array}$ & $\begin{array}{c}\mathrm{p} \\
\text { value }\end{array}$ \\
\hline BAD $(\mathrm{mm})$ & $37.7 \pm 4.03$ & $35.0 \pm 4.59$ & 0.012 \\
FMD diameter $(\mathrm{mm})$ & $41.18 \pm 3.91$ & $42.50 \pm 4.36$ & 0.55 \\
EDVR (\%) & $9.30 \pm 3.56$ & $18.68 \pm 8.21$ & 0.001 \\
\hline $\begin{array}{l}\text { BAD: baseline brachial artery diameter; FMD: flow-mediated dilatation; EDVR: } \\
\text { endothelial dependent vasodilatory response; Data are presented as mean } \pm \text { SD and } \\
\text { number (percentage) }\end{array}$
\end{tabular}

strated that cells derived from abnormal cutaneous scar tissue produce more TGF- $\beta$ than normal skin cells.

In the previous studies, keloid was found to be associated with cardiovascular diseases. Dustan et al. (19) hypothesized that keloid formation may be associated with an increased risk of hypertension and vascular disease among the black population. Moreover, Ozdol et al. (20) investigated the percutaneously revascularized patients and suggested that patients with proliferative scars may have a higher risk of in-stent restenosis. In a similar study, Johnsen et al. (21) found that carotid total plaque area, which is a stronger predictor of coronary events than intima media thickness, was significantly higher in keloid patients (22).

It is well known that atherosclerosis is a chronic inflammatory process occurring within the arterial wall at the atherosclerotic plaque site (23-25). Atherosclerosis shares similar components with proliferative scars $(26,27)$. Microscopically, 
atherosclerotic plaques essentially have 3 components: 1 - cells, including vascular smooth muscle cells, blood-derived monocytes/macrophages, and a scattering of lymphocytes; 2- connective tissue fibers and matrix; and 3- lipids. Although accumulation of low density lipoprotein in the subendothelial space initiates cellular migration and extracellular matrix formation, similar cell types and growth factors take part in the development of both atherosclerosis and proliferative scars (28).

It has been shown in previous studies that adventitial fibroblasts play a significant role in inflammation of the arterial wall and pathogenesis of atherosclerosis $(29,30)$. Lan et al. (31) showed that TGF- $\beta$ plays a critical role in extracellular matrix accumulation and vascular remodeling that is linked with many pathological progresses, including atherosclerosis. Dol-Gleizes et al. (32) postulated that fibroblast growth factors have an important role in the development of vascular diseases like atherosclerosis and graft arteriosclerosis. Furthermore, Sánchez-Escuredo et al. (33) found that VEGF was one of the markers of carotid atherosclerosis in renal transplant patients.

Although keloid and atherosclerosis have many points in common, there are only some data about their relation. Endothelial dysfunction is a well-known marker of atherosclerosis. Moreover, it has already been shown that EDVR was reduced in patients with coronary artery disease and that such reduction in EDVR was related to the extent of disease. Therefore, EDVR at the brachial artery is likely to represent a reliable indicator of atherosclerotic burden (34).

There is hardly any literature available investigating the relationship between keloid and endothelial function in surgically revascularized patients. In the present study, we showed that EDVR was significantly lower in the keloid group than the control group. As discussed before, more prominent endothelial dysfunction means more prominent atherosclerosis. In the light of the data, we might state that atherosclerosis is a wound healing abnormality. Since atherosclerosis grows more aggressively in the keloid group, we could also state that patients with proliferative scars after coronary artery bypass grafting operations might need further surgical or percutaneous revascularization interventions in the future than patients who do not have these scars.

In conclusion, in the present study, we concluded that endothelial dysfunction was more prominent in proliferative scar patients. If we focus on the close relationship between proliferative scars and atherosclerotic processes we might hypothesize that athersoclerosis is a wound healing abnormality. Furthermore, patients with proliferative scars might need additional revascularization interventions in the future. Of course further studies with larger cohorts of patients are needed to confirm these data.
Ethics Committee Approval: Ethics committee approval was received for this study from the ethics committee of Trabzon Numune Training and Research Hospital Ethic Comittee of Noninvasive Clinical Researches (App No: 07-2011).

Informed Consent: Written informed consent was obtained from patients who participated in this study.

Peer-review: Externally peer-reviewed.

Author contributions: Concept - M.Z., S.Ş.; Design - M.Z., S.Ş., Z.A.; Supervision - M.Z.; Resource - M.Z., O.Ş.; Materials - M.Z., S.Ş., O.Ş.; Data Collection \&/or Processing - M.Z., S.Ş.; Analysis \&/ or Interpretation - M.Z., Z.A.; Literature Search - M.Z., S.Ş., O.Ş., Z.A.; Writing - M.Z., S.Ş.; Critical Reviews - M.Z., S.Ş., Z.A., O.Ş.

Conflict of Interest: No conflict of interest was declared by the authors.

Financial Disclosure: The authors declared that this study has received no financial support.

\section{REFERENCES}

1. Ross R. Atherosclerosis--an inflammatory disease. $N$ Engl J Med 1999;340:115-26. [CrossRef]

2. Schillinger M, Exner M, Mlekusch W, Sabeti S, Amighi J, Nikowitsch R, et al. Inflammation and carotid artery risk for atherosclerosis study (ICARAS). Circulation 2005;111:2203-9. [CrossRef]

3. Tedgui A, Mallat Z. Cytokines in atherosclerosis: pathogenic and regulatory pathways. Physiol Rev 2006;86:515-81. [CrossRef]

4. Schroeder S, Kopp AF, Baumbach A, Meisner C, Kuettner A, Georg C, et al. Noninvasive detection and evaluation of atheroscleotic coronary plaques with multislice computed tomography. J Am Coll Cardiol 2001;37:1430-5. [CrossRef]

5. Mathers CD, Loncar D. Projections of global mortality and burden of disease from 2002 to 2030. PLoS Med 2006;3:e442. [CrossRef]

6. Caplan BA, Schwartz CJ. Increased endothelial cell turnover in areas of in vivo Evans blue uptake in the pig aorta. Atherosclerosis 1973;17:401-17. [CrossRef]

7. Sprague EA, Steinbach BL, Nerem RM, Schwartz CJ. Influence of a laminar steady-state fluid-imposed wall shear stress on the binding, internalization, and degradation of low-density lipoproteins by cultured arterial endothelium. Circulation 1987;76:64856. [CrossRef]

8. Ross R. The pathogenesis of atherosclerosis--an update. $N$ Engl J Med 1986;314:488-500. [CrossRef]

9. Park JH, Park TH, Chang CH. Earring embedded within earlobe keloids. Arch Plast Surg 2013;40:466-7. [CrossRef]

10. Köse O, Waseem A. Keloids and Hypertrophic Scars: Are they two different sides of the same coin? Dermatol Surg 2008;34:336-46. [CrossRef] 
11. Liao WT, Yu HS, Arbiser JL, Hong CH, Govindarajan B, Chai $\mathrm{CY}$, et al. Enhanced MCP-1 release by keloid CD14+ cells augments fibroblast proliferation: role of MCP-1 and Akt pathway in keloids. Exp Dermatol 2010;19:142-50. [CrossRef]

12. Ross, R. Atherosclerosis is an inflammatory disease. Am Heart $J$ 1999;138:419-20. [CrossRef]

13. Vogel RA. Measurement of endothelial function by brachial artery flow-mediated vasodilation. Am J Cardiol 2001;88:31E34E. [CrossRef]

14. Vinay K, Ramzi K, Stanley LR. Basic pathology $6^{\text {th }}$ edition. W.B. Saunders company; 1997. p. 55-6.

15. Robles DT, Berg D. Abnormal wound healing: keloids. Clin Dermatol 2007;25:26-32. [CrossRef]

16. Bian D, Zhang J, Wu X, Dou Y, Yang Y, Tan Q, et al. Asiatic acid isolated from centella asiatica inhibits TGF- $\beta 1$-induced collagen expression in human keloid fibroblasts via PPAR- $\gamma$ activation. Int J Biol Sci 2013;9:1032-42. [CrossRef]

17. Wynn TA. Cellular and molecular mechanisms of fibrosis. $J$ Pathol 2008;214:199-210. [CrossRef]

18. Wang R, Ghahary A, Shen Q, Scott PG, Roy K, Tredget EE. Hypertrophic scar tissues and fibroblasts produce more transforming growth factor-beta $1 \mathrm{mRNA}$ and protein than normal skin and cells. Wound Repair Regen 2000;8:128-37. [CrossRef]

19. Dustan HP. Does keloid pathogenesis hold the key to understanding black/white differences in hypertension severity? Hypertension 1995;26:858-62. [CrossRef]

20. Ozdol C, Turhan S, Tulunay C, Altin AT, Atmaca Y, Candemir $\mathrm{B}$, et al. Association between proliferative scars and in-stent restenosis. J Cutan Med Surg 2007;11:206-10. [CrossRef]

21. Johnsen SH, Mathiesen EB, Joakimsen O, Stensland E, Wilsgaard T, Lochen ML, et al. Carotid atherosclerosis is a stronger predictor of myocardial infarction in women than in men: a 6-year follow-up study of 6226 persons: the Tromso Study. Stroke 2007;38:2873-80. [CrossRef]

22. Bhavsar S, Nimigan A, Hackam DG, Gorman DB, Gan BS, Spence JD. Keloid scarring, but not Dupuytren's contracture, is associated with unexplained carotid atherosclerosis. Clin Invest Med 2009;32:95-02.

23. Van der Meer IM, Del Sol IA, Hak AE, Bots ML, Hofman A, Witteman JCM. Risk factors for progression of atherosclerosis measured at multiple sites in the arterial tree: the Rotterdam study. Stroke 2003;34:2374-9. [CrossRef]

24. Kadar A, Glasz T. Development of atherosclerosis and plaque biology. Cardiovasc Surg 2001;9:109-21. [CrossRef]

25. Van der Wal AC, Becker AE, M. van der Loos CM, Das PK. Site of intimal rupture or erosion of thrombosed coronary atherosclerotic plaques is characterized by an inflammatory process irrespective of the dominant plaque morphology. Circulation 1994;89:36-44. [CrossRef]

26. Ross R, Glomset J, Harker L. Response to injury and atherogenesis. Am J Pathol 1977;86:675-84.

27. Haust MD. Reaction patterns of intimal mesenchyme to injury, and repair in atherosclerosis. Adv Exp Med Biol 1974;43:35-57. [CrossRef]

28. Vinay K, Ramzi K, Stanley L.R. Basic pathology $6^{\text {th }}$ edition. W.B. Saunders company; 1997. p. 285-8.

29. Scott NA, Cipolla GD, Ross EC, Dunn B, Martin FH, Simonet $\mathrm{L}$, et al. Identification of a potential role for the adventitia in vascular lesion formation after balloon overstretch injury of porcine coronary arteries. Circulation 1996;93:2178-87. [CrossRef]

30. Shi Y, O'Brien JE Jr, Mannion JD, Morrison RC, Chung W, Fard A, et al. Remodeling of autologous saphenous vein grafts: the role of perivascular myofibroblasts. Circulation 1997;95:268493. [CrossRef]

31. Lan TH, Huang XQ, Tan HM. Vascular fibrosis in atherosclerosis. Cardiovasc Pathol 2013;22:401-7. [CrossRef]

32. Dol-Gleizes F, Delesque-Touchard N, Marès AM, Nestor AL, Schaeffer P, Bono F. A new synthetic FGF receptor antagonist inhibits arteriosclerosis in a mouse vein graft model and atherosclerosisin apolipoprotein E-deficient mice. PLoS One 2013;4:e80027. [CrossRef]

33. Sánchez-Escuredo A, Pastor MC, Bayés B, Morales-Indiano C, Troya M, Dolade M, et al. Inflammation, metalloproteinases, and growth factors in the development of carotid atherosclerosis in renal transplant patients. Transplant Proc 2010;42:2905-7. [CrossRef]

34. Manganaro A, Ciracì L, Andrè L, Trio O, Manganaro R, Saporito F, et al. Endothelial dysfunction in patients with coronary artery disease: Insights from a flow-mediated dilation study. Clin Appl Thromb Hemost 2014;25. [CrossRef] 